associated with hepatitis B virus was possible. Without liver biopsy the question of whether viral DNA has become integrated into the host genome of hepatocytes remains unanswered.

Continued study of carriers in the West may clarify the relative importance of the hepatitis B virus and genetic and environmental factors in causing liver disease. ${ }^{22}$

This project was supported by a grant from the Medical Research Council. We acknowledge the help and support of Dr T H Flewett, Professor A S McNeish, and the general practitioners and families of those children in the study. We also thank Mrs C Atherton and Miss T Mason for carrying out the assays; Dr Paul Jackson for clinical help; and Mrs K Rogers, Miss S Jacobs, and Mrs Pam Jackson for secretarial help.

\section{References}

1 Beasley RP, Hwang L-Y, Lin C-C, et al. Incidence of hepatitis B virus infections in preschool children in Taiwan. $\mathcal{F}$ Infect Dis 1982;146:198-204.

1a Szmuness $W$. Hepatocellular carcinoma and the hepatitis $B$ virus: evidence for a causal association. Prog Med Virol 1978:24:40-69.

2 Beasley RP, Hwang L-Y, Lin C-C, Chien C-S. Hepatocellular carcinoma and hepatitis B virus. Lancet 1981;ii:1129-33.

3 Beasley RP. Hepatitis B virus as the etiologic agent in hepatocellular carcinoma-epidemiologic considerations. Hepatology 1982;2:21-6S

4 Arthur MJP, Hall AJ, Wright R. Hepatitis B, hepatocellular carcinoma, and strategies for prevention. Lancet 1984;i:607-10.

5 Beasley RP, Hwang L-Y. Epidemiology of hepatocellular carcinoma. In: Vyas GN, Dienstag JL, Hoofnagle JH, eds. Viral hepatitis and liver disease. Orlando: Grune and Stratton, 1984:209-24.

6 Derso A, Boxall EH, Tarlow MJ, Flewett TH. Transmission of HBsAg from mother to infant in four ethnic groups. Br Med f 1978;i:949-52.
7 Beasley RP, Stevens CE. Vertical transmission of HBV and interruption with globulin. In: Vyas GN, Cohen SN, Schmid R, eds. Viral hepatitis. Philadelphia: Franklin Institute Press, GN, Cohen $1978: 333-45$.

8 Atherton CJ, Boxall EH. A sensitive screening test for the simultaneous detection of hepatitis B surface antigeri and antibody. $\mathcal{F}$ Virol Methods (in press).

9 Supran EM, Boxall EH, Craske J, Hart RJ, Vandervelde EM, Gardner PS. Enzyme linked mmunosorbent assay (ELISA) for the detection of hepatitis B e antigen and antibody: report of a field trial. $\mathcal{F}$ Clin Pathol 1983;36:581-5.

10 Hall AJ, Winter PD, Wright R. Mortality of hepatitis B positive blood donors in England and Wales. Lancet 1985; i:91-3.

11 Beasley RP, Shiao I-S, Wu T-C, Hwang L-Y. Hepatoma in an HBsAg carrier-seven years after perinatal infection. $\mathcal{J}$ Pediatr 1982;101:83-4.

12 Karayiannis P, Fowler MJF, Lok ASF, Greenfield C, Monjardino J, Thomas HC. Detection of HBV-DNA by molecular hybridisation. Correlation with HBeAg/Anti-HBe status, racia origin, liver histology and hepatocellular carcinoma. Foumal of Hepatology 1985:1:99-106.

13 Said S, Larouze B, Biaud JM, et al. Seroepidemiology of hepatitis B in a population of children in central Tunisia. Int f Epidemiol 1985;14:313-7.

14 Szmuness W, Harley EJ, Ikram $H$, Stevens CE. Sociodemographic aspects of the epidemiology of hepatitis B. In: Vyas GN, Cohen SN, Schmid R, eds. Viral hepatitis. Philadelphia: Franklin

15 Blumberg BS, Sutnick AI, London WT, Melartin L. Sex distribution of Australian antigen. Arch Intern Med 1972;130:227-31.

16 Blumberg BS. Sex differences in response to hepatitis B virus. Arthritis Rheum 1979;22:1261-6.

17 Glezen WP, Denny FW. Epidemiology of acute lower respiratory disease in children. $N$ Engl $\mathcal{J}$ Med 1973;288:498-505.

18 Viola LA, Barrison IG, Coleman JC, Paradinas FJ, Murray-Lyon IM. The HBe antigen-antibody system and its relationship to clinical and laboratory findings in 100 chronic HBsAg carriers in Great Britain. Med Virol 1981;8:169-75.

19 Realdi G, Alberti A, Rugge M, et al. Seroconversion from hepatitis B e antigen to anti-HBe in chronic hepatitis B virus infection. Gastroenterology 1980;79:195-9.

20 Thomas HC, Pignatelli M, Goodall A, Waters J, Karayiannis P, Brown D. Immunologic mechanisms of cell lysis in hepatitis B virus infection. In: Vyas GN, Dienstag JL, Hoofnagle mechanisms of cell lysis in hepatitis B virus infection. In: Vyas GN, Dienstag JL,

21 Skinhoj $P$. Infection with hepatitis B virus in infancy. Arch Dis Child 1978;53:746-8.

22 Lutwick LI. Relation between aflatoxin, hepatitis B virus, and hepatocellular carcinoma. Lancet 1979;: :755-7.

(Accepted 30 October 1986)

\title{
Psychiatric disorder and gynaecological symptoms in middle aged women: a community survey
}

\author{
DENNIS GATH， MADELINE OSBORN， GEOFFREY BUNGAY，SUSAN ILES， ANN DAY, \\ ALISON BOND, CLARE PASSINGHAM
}

\begin{abstract}
In a community survey 521 women aged 35-59 were selected at random from all patients registered in two group practices. They were interviewed at home and assessed by means of standardised psychiatric measures and detailed gynaecological inquiry. Levels of psychiatric morbidity were found to be within the expected range for such a sample. Both psychiatric morbidity and the personality dimension of neuroticism were significantly
\end{abstract}

University Department of Psychiatry, Warneford Hospital, Oxford OX3 7JX DENNIS GATH, FRCP, FRCPSYCH, clinical reader in psychiatry

SUSAN ILES, DPHIL, MRCPSYCH, Wellcome research fellow

ANN DAY, research assistant

ALISON BOND, BA, research assistant

CLARE PASSINGHAM, BA, research assistant

Manchester Royal Infirmary, Manchester M13 9BX

MADELINE OSBORN, MB, MRCPSYCH, consultant psychiatrist

Oxford Regional Health Authority, Headington, Oxford

GEOFFREY BUNGAY, MB, MRCM, community physician

Correspondence to: Dr Gath. associated with gynaecological symptoms, including dysmenorrhoea and premenstrual tension, some symptoms of excessive menstruation, and flushes and sweats but not disappearance of menstruation for over six months. Current psychiatric state was significantly associated with recent adverse life events and with indices of psychiatric vulnerability (neuroticism and previous psychiatric history), suggesting possible aetiological links with gynaecological symptoms.

The findings of this study have implications for the management of gynaecological complaints in general practice.

\section{Introduction}

Clinical experience has led some gynaecologists and psychiatrists to conclude that gynaecological symptoms are commonly linked with psychiatric disorder..$^{1-4}$ For example, an American gynaecologist maintained that "many patients present gynaecological symptoms without being sick gynaecologically. Their illness represents a psychic conflict sailing under a gynaecological flag."

There is some research to support these clinical impressions. In three recent studies ${ }^{5-7}$ women attending gynaecological clinics were assessed with the self rated general health questionnaire. ${ }^{8}$ In each study about half the women were identified as probable psychiatric cases. These levels of morbidity seem impressively high, but they are difficult to evaluate without comparable information on women attending other kinds of medical or surgical clinic.

Conversely, there is some evidence for increased gynaecological 
morbidity among psychiatric patients. For example, a history of gynaecological surgery was found more frequently among patients diagnosed as having hysteria than among controls.' In another study, an increased frequency of menstrual disorders was found among patients with various neurotic disorders. ${ }^{10}$

Most reported associations have been between menstrual symptoms and psychiatric state or neurotic personality. In community surveys in Australia symptoms of dysmenorrhoea were found to be associated with both psychiatric symptoms and neuroticism. "In the United Kingdom Clare used the general health questionnaire to assess women attending general practitioners and found an association between premenstrual tension and psychiatric state. ${ }^{12}$

Symptoms of excessive menstruation were found to be associated with psychiatric state in a postal survey in Dundee ${ }^{13}$ and an interview study of women awaiting hysterectomy in Oxford. ${ }^{14}$

The extent of an association between the menopause and psychiatric disorder has been controversial. Conflicting findings may reflect differences in the populations studied and in the definition of the menopause. In a postal survey Ballinger found that psychiatric morbidity, as assessed with the general health questionnaire, was highest in women who had stopped menstruating in the past three to 12 months. ${ }^{13}$ In another postal survey Bungay and colleagues found that minor psychiatric symptoms peaked just before the mean menopausal age, though vasomotor symptoms peaked around the mean age of the menopause. ${ }^{15}$ In hospital based research Winokur and Cadoret found no association between the menopausal years and admissions for depression or attempted suicide. ${ }^{16} 17$ From a review of published work Weissman and Klerman concluded that there was no evidence that women are at greater risk of depression during the menopausal period. ${ }^{18}$

Menstrual and menopausal complaints are common in middle life-that is, the late 30 s to early 50 s. From studies in general practice there is evidence that emotional disorders are also common in women of this age. For example, in a large study of London general practices by Shepherd and colleagues twice as many female as male patients were identified as suffering from psychiatric illnesses, and the prevalence of psychiatric illness was highest in the middle years for women. ${ }^{19}$ In a study of six group practices in Oxford Skegg and colleagues found that the rates of prescribing of psychotropic drugs were highest among registered women aged $45-59 .{ }^{20}$

Against this background we decided to examine relations between psychiatric morbidity and gynaecological symptoms among middle aged women registered in general practice. For this purpose it seemed important to obtain information by interview rather than by postal questionnaire and to use standardised methods of assessment.

The main aims of the study were to answer three questions in relation to women aged $35-59$ in the community: How many currently have (a) psychiatric disorders, $(b)$ gynaecological symptoms, and $(c)$ both psychiatric disorders and gynaecological symptoms?

This paper focuses on findings in relation to the first and third questions. Separate papers on the detailed patterns of gynaecological symptoms, and on psychosexual functioning, are in preparation.

\section{Subjects and methods}

\section{RECRUITMENT}

The study was based on two Oxford group practices with computerised age and sex registers. The computer was used to identify all registered women aged 35-59 and to select from them a random sample of 600 women, consisting of 100-150 women in each of five age bands (35-39, 40-44, 45-49, 50-54, and 55-59).

The 600 women were sent a letter signed by their general practitioner explaining the purpose of the study and inviting participation. Of the 600 women, $521(87 \%)$ agreed to be interviewed; in the five age bands from youngest to oldest the numbers agreeing were $96(91 \%), 99(91 \%), 98(80 \%)$, $99(87 \%)$, and $129(86 \%)$.
ASSESSMENT

The 521 women were interviewed in their homes by women researc assistants from the department of psychiatry, all of whom were experienced in interviewing gynaecological patients. The interview was semistructured and focused mainly on psychiatric and gynaecological health.

In the psychiatric part four standardised measures were used. Curre $\overline{\overline{\mathbf{m}}}$ psychiatric state was assessed with a standardised interview and a self rated questionnaire-namely, the present state examination ${ }^{21}$ and the generef health questionnaire. ${ }^{8}$ The personality dimension of neuroticism wass measured with the Eysenck personality inventory. ${ }^{22}$ The social adjustment scale, as modified by Cooper $e t a l,{ }^{23}$ was used to measure social functioningThe gynaecological part was compiled with help from local gynaec 19 logists. It was detailed, covering all standard areas of gynaecological inquirs and particularly those reviewed above (dysmenorrhoea, premenstrua tension, excessive menstruation, and the menopause).

In this paper the term "gynaecological symptoms" refers to responses given by the survey women to this gynaecological functional inquiry. The term does not imply that women necessarily found such symptoms distressing or regarded them as abnormal. (Some questions, however, were concerned with distress or perceived abnormality.)

The interview also included sections on psychosexual functioning, the interview for recent life events, ${ }^{24}$ and history of consultations with the general practitioner and specialists.

\section{ANALYSIS OF DATA}

Frequencies of gynaecological symptoms, psychiatric disorder, and consultation behaviour were derived for the study population as a whole and when appropriate, by age bands. Associations between gynaecologica symptoms and various measures of psychiatric disorder were examined by comparisons of groups using $t$ tests, Pearson's test, or Spearman's test for continuous variables-for example, total scores in the present state examination, neuroticism in the Eysenck personality inventory-and the $\chi^{2}$ test for ordinal variables-for example, "caseness."

\section{Results}

The marital state of the 521 women was: currently married, $426(82 \%$ cohabiting, $12(2 \%)$; single, $32(6 \%)$; divorced or separated, $31(6 \%$ widowed, $20(4 \%)$. A total of $418(80 \%)$ of the women were in para employment, mostly part time. Of their partners, 395 (90\%) were in parif employment. The social class distribution was: classes I and II, 204 womea (39\%); class III, 220 (42\%); classes IV and V, 85 (16\%); unknown, $12(2 \% \overrightarrow{\vec{E}}$ Compared with the corresponding figures for Oxford city $(27 \%, 45 \%, 26 \%$ and $2 \%$ ) the sample was over-represented in classes I and II and undeg represented in classes IV and V $\left(\chi^{2}=44 \cdot 577 ; p<0 \cdot 001\right)$.

Results are presented under three main headings: current psychiatric state, relations between current psychiatric state and gynaecologica्य symptoms, and relations between current psychiatric state and consultation for gynaecological complaints.

\section{CURRENT PSYCHIATRIC STATE}

Table I gives the results.

\section{Present state examination}

Of the 521 women interviewed, 520 were assessed with the present state examination. When index of definition level 5 and above was used to identify psychiatric cases, 50 women $(9 \cdot 6 \%)$ were cases. This level of morbidit did not differ notably from those reported among women in other genera population samples (further explained below). Patients who were psychiatric cases at index of definition level 5 and above were divided integ CATEGO classes, which are roughly equivalent to ICD (9th revision diagnoses. ${ }^{21}$ The distribution in the sample was: neurotic depression $19(38 \%)$; anxiety state, $15(30 \%)$; retarded depression, 14 (28\%); manio state, $2(4 \%)$. These figures were within the expected range.

For the sample as a whole (cases and non-cases) syndrome profiles wers derived. ${ }^{21}$ The most frequent syndromes were worry (165 women, 32\%) ang tension $(119,23 \%)$, followed by irritability $(72,14 \%)$, somatic features 0 . depression $(71,14 \%)$, situational anxiety $(71,14 \%)$, social unease $(70,13 \%$ general anxiety $(56,11 \%)$, and simple depression $(48,9 \%)$. 


\section{General health questionnaire}

The general health questionnaire was completed by 490 women. With this questionnaire, which detects psychiatric morbidity at a lower threshold than the present state examination, the numbers of high scorers were $85(17 \cdot 3 \%)$ on the 60 item questionnaire and $104(21 \cdot 2 \%)$ on the 28 item questionnaire. These levels were within the expected range.

\section{Relation between current psychiatric state and age, social class, neuroticism, and psychiatric history (table ii)}

Age-There were no significant relations between current psychiatric state and age, except for a significant excess of high scorers in the 60 item general health questionnaire in the age band $50-54$. examination and the 60 item general health questionnaire, was associated strongly with painful periods and with periods interfering with life, but less strongly with the use of medication for period pain. The personality characteristic of neuroticism was associated strongly with all indices of period pain.

\section{Premenstrual tension}

Information on premenstrual tension was obtained from 264 of the 265 premenopausal women. The women were given a list of five physical and five psychological symptoms and asked how often during the past six months these symptoms had occurred in the five days preceding the onset of menstruation. The women were asked to rate frequencies on a four point scale: no periods ( 0 ); occasional periods ( 1 ); most periods (2); all periods (3).

TABLE I-Current psychiatric state of survey sample. Results expressed as proportions of women rated as psychiatric cases in present state examination and as high scorers in 60 and 28 item general health questionnaires

\begin{tabular}{llcc}
\hline \multicolumn{1}{c}{ Psychiatric measure } & \multicolumn{1}{c}{ Cut off point } & $\begin{array}{c}\text { No of } \\
\text { women assessed }\end{array}$ & $\begin{array}{c}\text { No (\%) of psychiatric } \\
\text { cases/high scorers }\end{array}$ \\
\hline Present state examination & Index of definition level 5 and above & 520 & $50(9 \cdot 6)$ \\
General health questionnaire $(60$ item) & Total score $\geqslant 12$ & 490 & $85(17 \cdot 3)$ \\
General health questionnaire $(28$ item) & Total score $\geqslant 5$ & 490 & $104(21 \cdot 2)$ \\
\hline
\end{tabular}

TABLE II-Relation between current psychiatric state and age, social class, neuroticism, and psychiatric history

\begin{tabular}{|c|c|c|c|c|c|}
\hline & \multicolumn{5}{|c|}{ Psychiatric state } \\
\hline & \multicolumn{2}{|c|}{ Present state examination } & \multicolumn{2}{|c|}{ General health questionnaire } & \multirow{2}{*}{$\frac{\text { Eysenck personality inventory }}{\begin{array}{c}\text { Neuroticism } \\
(t \text { test })\end{array}}$} \\
\hline & $\begin{array}{c}\text { Case } \\
\left(\chi^{2} \text { test }\right)\end{array}$ & $\begin{array}{c}\text { Total score } \\
(t \text { test or Pearson's test) }\end{array}$ & $\begin{array}{l}\text { High scorers } \\
\left(\chi^{2} \text { test }\right)\end{array}$ & $\begin{array}{c}\text { Total score } \\
\text { ( } t \text { test or Pearson's test) }\end{array}$ & \\
\hline $\begin{array}{l}\text { Age band } 50-54 \text { years }(n=99) \\
\text { Other age bands }(n=422) \\
\text { Social class }(n=509) \\
\text { Neuroticism }(n=504) \\
\text { Previous psychiatric history }(n=62) \\
\text { Family psychiatric history }(n=97)\end{array}$ & $\begin{array}{l}\text { NS } \\
\text { NS } \\
\text { NS } \\
\star \star \star \\
\star \star \star \\
\star \star\end{array}$ & $\begin{array}{l}\text { NS } \\
\text { NS } \\
\text { NS } \\
\star \star \star \\
\star \star \star \\
\star\end{array}$ & 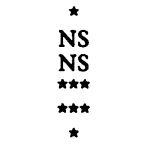 & $\begin{array}{l}\text { NS } \\
\text { NS } \\
\text { NS } \\
\star \star \star \\
\star \star \\
\text { NS }\end{array}$ & $\begin{array}{l}\text { NS } \\
\text { NS } \\
\text { NS } \\
-\star \\
\text { NS }\end{array}$ \\
\hline
\end{tabular}

${ }^{\star} p<0.05 .{ }^{\star \star} p<-0.01 .{ }^{\star \star \star} p<0.001$

Social class was not significantly related to any measure of psychiatric state.

Neuroticism-As measured by the Eysenck personality inventory, the personality dimension of neuroticism was significantly associated with all indices of current psychiatric state.

Psychiatric history-Indices of current psychiatric state were strongly related to the woman's personal history of referral to a psychiatrist at any time. There were similar but weaker associations with a family history of psychiatric referral.

\section{RELATION BETWEEN CURRENT PSYCHIATRIC STATE AND GYNAECOLOGICAL SYMPTOMS}

Excluding four women who were pregnant, the remaining 517 women were classified as premenopausal if they had had at least one menstrua period in the past six months and as postmenopausal if they had had no menstrual periods in that time. By this classification $265(51 \%)$ of the 521 women were premenopausal and $252(49 \%)$ postmenopausal.

\section{Dysmenorrhoea}

Of the 265 premenopausal women, $152(57 \%)$ reported painful periods in the past six months. Within this group 40 women $(26 \%)$ reported that period pain had interfered with everyday life and $96(63 \%)$ usually took medication for pain. In the past six months seven women had consulted their doctor about period pains, two of them being referred to a gynaecologist.

Table III shows the relation between dysmenorrhoea and psychiatric state. Current psychiatric state, as determined by both the present state
As many as 251 women (95\%) said that they had experienced symptoms of premenstrual tension (physical or psychological, or both) during the past six months. The extent to which individual symptoms were rated 2 or 3 (most or all periods) was as follows: (a) physical symptoms-abdominal/face/ finger/ankle distension $140(53 \%)$, breast swelling/tenderness 127 (48\%), abdominal pain 81 (31\%), headaches $56(21 \%)$, other $17(6 \%)$; (b) psychological symptoms-irritability 150 (57\%), anxiety/tension 125 (47\%), tiredness $104(39 \%)$, depression 69(26\%), other 12(5\%). Despite the frequency of these symptoms only 20 women $(8 \%)$ reported that the symptoms interfered with normal activities, and only $2 \%$ rated such interference as severe. Use of medication to alleviate premenstrual tension, however, was reported by as many as 65 women $(25 \%)$. Sixteen women (6\%) had consulted their doctor for premenstrual tension in the past six months and two had been referred to a gynaecologist.

Table III shows that current psychiatric state, as determined by both the present state examination and the general health questionnaire, was significantly related to both psychological and physical symptoms of premenstrual tension and to interference with life due to premenstrual tension. The personality dimension of neuroticism was significantly associated with all the indices of premenstrual tension, including the use of medication for the condition.

\section{Excessive menstruation}

In the assessment of excessive menstruation use was made of four "objective" indices (flooding, clots, duration of periods, number of pads or tampons used) and two "subjective" indices (estimated heaviness of period, interference with life).

When asked about the objective indices in the past six months 37 women ( $14 \%)$ reported flooding on six or more days, while 84 women ( $32 \%)$ reported 
TABLE III-Relation between psychiatric state and dysmenorrhoea and premenstrual tension

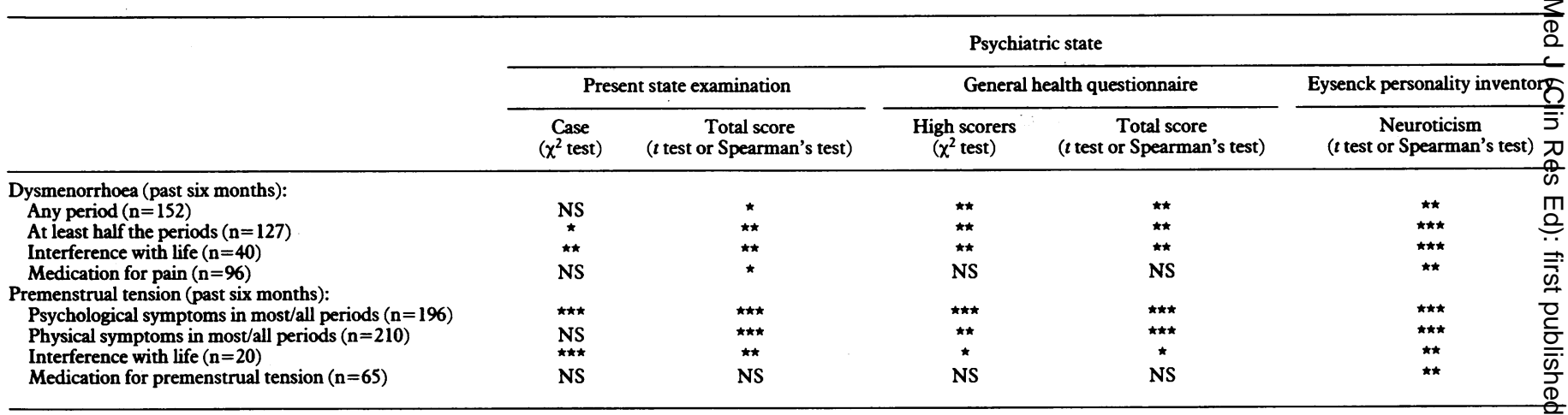

${ }^{\star} \mathrm{p}<0.05 .{ }^{\star \star} \mathrm{p}<0.01 .{ }^{\star \star \star} \mathrm{p}<0.001$.

TABLE IV-Relation between psychiatric state and indices of excessive menstruation

\begin{tabular}{|c|c|c|c|c|c|}
\hline \multirow[b]{3}{*}{$\begin{array}{l}\text { Indices of excessive menstruation } \\
\text { (past six months) }\end{array}$} & \multicolumn{5}{|c|}{ Psychiatric state } \\
\hline & \multicolumn{2}{|c|}{ Present state examination } & \multicolumn{2}{|c|}{ General health questionnaire } & \multirow{2}{*}{$\frac{\text { Eysenck personality inventory }}{\begin{array}{c}\text { Neuroticism } \\
(t \text { test })\end{array}}$} \\
\hline & $\begin{array}{c}\text { Case } \\
\left(\chi^{2} \text { test }\right)\end{array}$ & $\begin{array}{l}\text { Total score } \\
\quad(t \text { test })\end{array}$ & $\begin{array}{l}\text { High scorers } \\
\quad\left(\chi^{2} \text { test }\right)\end{array}$ & $\begin{array}{c}\text { Total score } \\
\quad(t \text { test })\end{array}$ & \\
\hline $\begin{array}{l}\text { Objective assessments: } \\
\text { Any flooding }(n=72) \\
\text { Flooding } \geqslant 6 \text { days }(n=37) \\
\text { Any clots }(n=125) \\
\text { Clots } \geqslant 6 \text { days }(n=84) \\
\text { Periods } \geqslant 6 \text { days }(n=91) \\
>6 \text { Pads on heaviest day }(n=86) \\
>8 \text { Pads on heaviest day }(n=38)\end{array}$ & $\begin{array}{l}\text { NS } \\
\text { NS } \\
\text { NS } \\
\text { NS } \\
\text { NS } \\
\text { NS } \\
\text { NS }\end{array}$ & $\begin{array}{l}\star \\
\text { NS } \\
\star \star \\
\text { NS } \\
\text { NS } \\
\text { NS } \\
\text { NS }\end{array}$ & $\begin{array}{l}\text { NS } \\
\text { NS } \\
\star \\
\text { NS } \\
\star \\
\text { NS } \\
\text { NS }\end{array}$ & $\begin{array}{l}\text { NS } \\
\text { NS } \\
\star \\
\text { NS } \\
\text { NS } \\
\text { NS } \\
\text { NS }\end{array}$ & 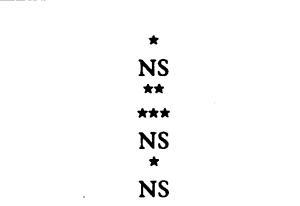 \\
\hline $\begin{array}{l}\text { Subjective assessments: } \\
\text { Very heavy periods }(n=16) \\
\text { Fairly heavy periods }(n=64) \\
\text { Interference with life from heavy periods }(n=59)\end{array}$ & $\begin{array}{l}\star \star \star \\
\text { NS } \\
\text { NS }\end{array}$ & $\begin{array}{l}\star \\
\text { NS } \\
\text { NS }\end{array}$ & $\begin{array}{l}\stackrel{\star}{\text { NS }} \\
\text { NS }\end{array}$ & $\begin{array}{l}\text { NS } \\
\text { NS } \\
\text { NS }\end{array}$ & $\begin{array}{l}\text { NS } \\
\text { NS } \\
\star\end{array}$ \\
\hline
\end{tabular}

${ }^{\star} \mathrm{p}<0.05 .{ }^{\star \star} \mathrm{p}<0.01 .{ }^{\star \star \star} \mathrm{p}<0.001$.

passing clots at the same frequency. There were 91 women $(34 \%)$ who reported all periods as lasting six or more days and $86(32 \%)$ who used more than six pads or tampons on the heaviest day of their period.

When asked about the subjective assessments 16 women $(6 \%)$ rated their periods as very heavy and $64(24 \%)$ as fairly heavy, while $103(39 \%)$ rated them as neither heavy nor light, $44(17 \%)$ as fairly light, $14(5 \%)$ as very light, and $23(9 \%)$ as variable. There were 59 women $(22 \%)$ who stated that heavy periods had interfered with their life.

Of 19 women $(7 \%)$ who had consulted their doctor for excessive menstruation in the past six months, seven had been referred to a gynaecologist.

Table IV shows the relations between psychiatric state and the indices of excessive menstruation listed above. The degree of association was considerably less than with dysmenorrhoea or premenstrual tension. Some measures of psychiatric state, however, were significantly associated with flooding and clots and also with the woman's subjective assessment of her periods as very heavy.

\section{Menopausal symptoms}

The 252 postmenopausal women could be divided into 174 (33\% of the 521 ) who had had a natural menopause and $78(15 \%)$ who had had a surgical menopause (hysterectomy with or without bilateral oophorectomy).

At the time of interview the mean age of the natural menopause group was 54.5 years (SD 4.01). In this group 22 women had experienced disappearance of menstruation recently (six to 12 months before interview), and their mean age at interview was 48.95 years (SD 4.76).

To examine the relation between psychiatric state and disappearance of periods the patients were divided into four groups: still menstruating (that is, premenopausal, as defined above); no periods for six to 12 months; no periods for one to six years; no periods for more than six years. There was no significant difference among these four groups in psychiatric state as determined by either the present state examination or the general health questionnaire.

In published work many symptoms have been described as menopausal, most of them non-specific-for example, headaches and dizziness. In this study the inquiry concentrated on the vasomotor symptoms flushes a agid sweats. Two groups of women were excluded from the analysis of vasomoter symptoms-namely, the four pregnant women and 24 women who had hæd bilateral oophorectomies (these women were excluded because we wege uncertain whether they had received hormone replacement therapy). The remained 493 women in whom vasomotor symptoms could reasonably be attributed to ovarian failure. In this group vasomotor symptoms had be experienced at some time in the past year by 205 women (42\%), at some time in the past month by $166(34 \%)$, and daily in the past month by $73(15 \%)$.

Table $\mathrm{V}$ shows the relation between psychiatric state and vasomoter symptoms. Both current psychiatric state (present state examination agid general health questionnaire) and neuroticism were related substantially the age group 45-49, less so to the age group 40-44, and not at all to the other age groups.

\section{Other gynaecological symptoms}

In the whole sample of 521 women $102(19 \cdot 6 \%)$ reported some streis incontinence in the preceding month. A subgroup of 41 women reportat stress incontinence occurring more often than weekly; on comparison mean scores this complaint was significantly related to age $(t=2 \cdot 28$, $\mathrm{p}<0.05)$, to neuroticism $(t=2.38 ; \mathrm{p}<0.01)$, and to total score in the preseit state examination $(t=2.27 ; \mathrm{p}<0.05)$.

Symptoms of uterine prolapse $(n=22 ; 4 \cdot 2 \%)$ and vaginal dischare $(\mathrm{n}=37 ; 7 \cdot 1 \%)$ were not significantly related to psychiatric state $\mathscr{G}_{\mathrm{r}}$ neuroticism.

\section{RELATION BETWEEN CURRENT PSYCHIATRIC STATE AND CONSULTATION FOR GYNAECOLOGICAL COMPLAINTS}

In the 12 months before interview among the 521 women the numbers consulting their general practitioner were $91(17 \%)$ for psychiate complaints and 127 (24\%) for gynaecological complaints. Up to a fifth these consultations were for repeat prescriptions.

Table VI shows that there were strong associations between psychiatric 
state and consultation with the general practitioner in the past six months because of dysmenorrhoea or any symptom of premenstrual tension. There was no significant association with complaints of heavy periods or vasomotor symptoms. There was also an interesting converse relation, in that consultation with the general practitioner for psychiatric complaints was strongly associated with survey symptoms of dysmenorrhoea, premenstrual tension, and also vasomotor symptoms (not shown in table).

\section{Discussion}

This study was a community survey in so far as the sample was randomly drawn from all the patients registered in two practices, and not just from patients consulting their general practitioner.

The levels of psychiatric morbidity found were similar to those in other community surveys. Thus the proportion of cases identified

TABLE V-Relation between psychiatric state and vasomotor symptoms by age

\begin{tabular}{|c|c|c|c|c|c|}
\hline \multirow[b]{3}{*}{ Vasomotor symptoms } & \multicolumn{5}{|c|}{ Psychiatric state } \\
\hline & \multicolumn{2}{|c|}{ Present state examination } & \multicolumn{2}{|c|}{ General health questionnaire } & \multirow{2}{*}{$\frac{\text { Eysenck personality inventory }}{\begin{array}{c}\text { Neuroticism } \\
(t \text { test })\end{array}}$} \\
\hline & $\underset{\left(x^{2} \text { test }\right)}{\text { Case }}$ & $\begin{array}{c}\text { Total score } \\
\quad(l \text { test })\end{array}$ & $\begin{array}{l}\text { High scorers } \\
\left(\chi^{2} \text { test }\right)\end{array}$ & $\begin{array}{c}\text { Total score } \\
\quad(t \text { test })\end{array}$ & \\
\hline \multicolumn{6}{|l|}{ Total sample $(n=493)$ : } \\
\hline Ever past year & NS & $\star \star$ & NS & * & $\star \star \star$ \\
\hline Ever pest month & NS & $\star \star$ & NS & NS & 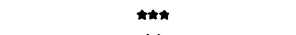 \\
\hline Daily past month & $\star$ & $\star \star \star \star$ & 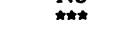 & $\star \star$ & $\star \star$ \\
\hline \multicolumn{6}{|l|}{ Age 40-44 (n=95): } \\
\hline Ever past year & NS & NS & NS & NS & 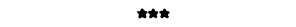 \\
\hline Ever past month & NS & NS & NS & NS & $\star \star \star \star$ \\
\hline Daily past month & $\star$ & $\star$ & NS & $\star$ & $\star$ \\
\hline \multicolumn{6}{|l|}{ Age $45-49$ ( $n=95):$} \\
\hline Ever past year & $\star$ & $\star \star \star$ & NS & $\star \star$ & $\star$ \\
\hline Ever past month & $\star$ & $\star \star$ & NS & NS & \#* \\
\hline Daily past month & NS & $\star$ & NS & NS & NS \\
\hline \multicolumn{6}{|l|}{ Other age groups ( $n=303)$ : } \\
\hline $\begin{array}{l}\text { Ever past year } \\
\text { Ever past month }\end{array}$ & NS & NS & NS & NS & NS \\
\hline Daily past month & & & & & \\
\hline
\end{tabular}

${ }^{\star} p<0.05 .{ }^{\star \star} p<0.01 .{ }^{\star \star \star} p<0.001$.

TABLE VI-Relation between psychiatric state and consultation with general practitioner for gymaecological complaints

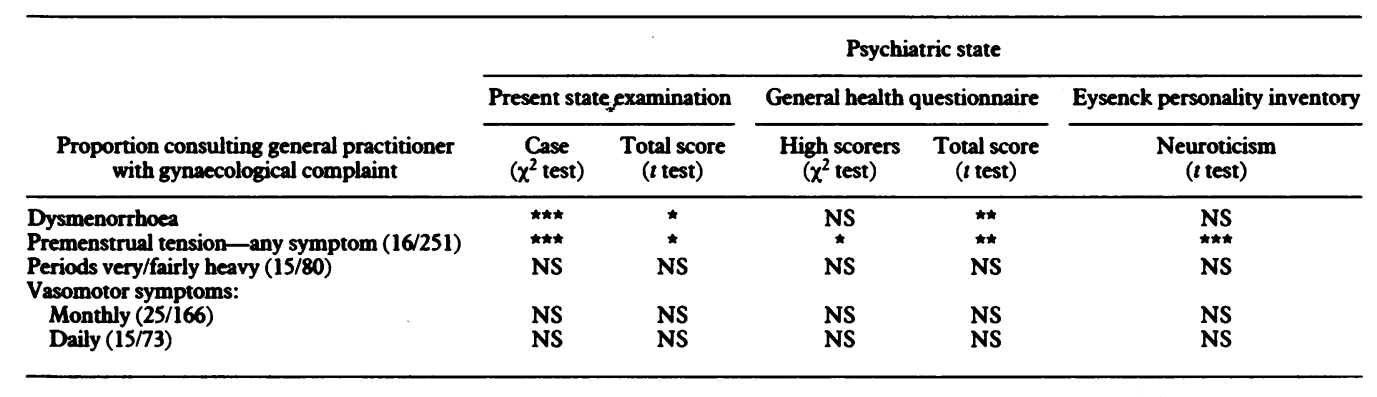

${ }^{\star} \mathrm{p}<0.05 .{ }^{\star \star} \mathrm{p}<0.01 .{ }^{\star \star \star} \mathrm{p}<0.001$

\section{LIFE EVENTS AND CHRONIC HEALTH PROBLEMS}

\section{Life events}

The interview for recent life events ${ }^{24}$ was used to identify potentially stressful events in the 12 months preceding interview. A single adverse event was reported by 101 women (19\%) and multiple adverse events by six women (1\%). Examples of such events were bereavements, illness of a family member, marital crises, or legal problems. These life events were strongly associated with case state in the present state examination $\left(\chi^{2}=10 \cdot 28\right.$; $\mathrm{p}<0.001)$ and total score in the present state examination $(t=2.87 ; \mathrm{p}<0.005)$ and with high scores in the general health questionnaire $\left(\chi^{2}=14.79\right.$; $\mathrm{p}<0.0001)$ and total score in the questionnaire $(t=2.67 ; \mathrm{p}<0.01)$. Life events were not significantly associated with any type of gynaecological symptom recorded in the survey.

\section{Chronic health problems}

Of the 521 patients interviewed, $23(4 \%)$ reported chronic health problems such as asthma, hypertension, or arthritis. When compared with women free from such health problems this subgroup had significantly higher mean scores in the 60 item general health questionnaire $(t=2 \cdot 16$; $\mathrm{p}<0.05)$ and for neuroticism $(t=4.14 ; \mathrm{p}<0.0001)$ but not for other psychiatric measures. by the present state examination was $\mathbf{9 \cdot 6 \%}$ among Oxford women, as against $12 \cdot 2 \%$ and $8 \cdot 7 \%$ in community samples of women in Camberwell ${ }^{25}$ and Edinburgh, ${ }^{26}$ respectively. Similarly, the proportion of high scorers detected with the 60 item general health questionnaire was $17 \cdot 3 \%$ in Oxford, as against $16.3 \%$ in a community sample of women in Manchester. ${ }^{27}$

Given that levels of psychiatric morbidity in the Oxford survey were not remarkable, the degree of association between gynaecological symptoms and psychiatric morbidity was striking. Among menstrual symptoms, for example, both dysmenorrhoea and premenstrual tension were strongly related to psychiatric state. Similar associations were found in Wood's community survey of dysmenorrhoea in Australia, ${ }^{11}$ and in Clare's study of premenstrual tension among women consulting their general practitioners in London. ${ }^{12}$ Arguably any apparent link between psychiatric state and premenstrual tension might simply result from an overlap in symptoms; but such an overlap would not explain the link found in Oxford between psychiatric state and the physical symptoms of premenstrual tension.

There were some significant associations of psychiatric state with indices of excessive menstruation, including clots, flooding, and subjective estimation of periods as very heavy. Generally, however, indices of excessive menstruation were not strongly related to 
mental state. This is surprising, since menorrhagia might be expected to induce emotional distress.

No clear association was found between psychiatric state and the so called "menopausal years." Thus there was no significant relation between any of the five age bands and psychiatric morbidity as detected by the present state examination and the 28 item general health questionnaire, though there was a significant excess of high scorers in the 60 item general health questionnaire in the age band 50-54. Notable also was that psychiatric state was not related to the disappearance of menstrual periods, whether recent or remote. Mental state, however, was substantially related to vasomotor symptoms in women aged 45-49, less so in women aged 40-44, and not at all in other age groups. This finding has implications for the aetiology of emotional symptoms in perimenopausal women. Vasomotor symptoms might be linked with emotional symptoms in two ways. Firstly, oestrogen deficiency might be a direct cause of both vasomotor symptoms and mood changes; secondly, oestrogen deficiency might lead to vasomotor symptoms, which in turn might be distressing enough to induce emotional symptoms. Such an explanation does not preclude the possibility that emotional symptoms in some perimenopausal women may be due to psychological and social factors.

Vasomotor symptoms apart, how are we to explain the strong associations found between other gynaecological symptoms and psychiatric disorder? Is there an aetiological link? Two sets of findings have an important bearing on this question. Firstly, psychiatric disorder and gynaecological symptoms appeared to occur together in women who were psychiatrically vulnerable. The evidence for psychiatric vulnerability was that the personality dimension of neuroticism was strongly associated not only with current psychiatric state but also with all types of gynaecological symptoms. Psychiatric vulnerability was also indicated by the strong associations of previous psychiatric history and family psychiatric history with current psychiatric state. The second important finding was that adverse life events were strongly related to current psychiatric disorder.

The combination of psychiatric vulnerability and adverse life events might provide several causal links between gynaecological symptoms and psychiatric disorder. For example, gynaecological symptoms might be primary and induce emotional symptoms in a vulnerable woman. Alternatively, in a vulnerable woman chronic marital or family difficulties might induce a primary psychiatric disorder, which might then make the woman more likely to pay attention to gynaecological symptoms, or find them distressing, or regard them as abnormal. In either example an adverse life event might act as a precipitant in the causal chain.

Our findings have certain implications for general practice. Thus if a woman presents in the surgery with a gynaecological complaint, particularly with a menstrual complaint, it is advisable to look for any associated psychiatric disorder. It is helpful to use a brief but dependable method of inquiry. An example is the brief interview described by Goldberg and Huxley, which focuses on the emotional symptoms most often met in general practice. ${ }^{28}$ General psychological adjustment is assessed by asking about fatigue, irritability, poor concentration, and the feeling of being under stress. Anxiety is assessed by asking about tension, persistent worrying thoughts, and phobias. Depressive symptoms are elicited by inquiring about persistent depressed mood, tearfulness, self blame, hopelessness, thinking that life is unbearable, and the "biological" symptoms of early morning waking, diurnal variation of mood, loss of weight, and loss of libido.

If a psychiatric disorder is detected in this way management will depend on whether or not a physical cause can be found for the gynaecological complaint. If a physical cause is detected the appropriate gynaecological treatment should be considered while bearing in mind that the associated psychiatric condition may be aggravating the extent to which the patient complains of her gynaecological symptoms. In some cases when gynaecological treatment is given the psychiatric symptoms will resolve as a consequence. In other cases the psychiatric symptoms will persist and, depending on their duration and severity, may require specific psychiatric treatment. In judging the severity of psychiatric symptoms it is useful to assess the amount of distress experienced beg the patient, the degree to which her functioning is impaired in the family or at work, and the presence of the biological symptoms mentioned above (usually indicating a disorder of at least moderateseverity).

If no physical cause is found for the gynaecological complaint $\overline{\bar{n}}$ can be helpful to establish as far as possible which came first, the gynaecological complaint or the psychiatric symptoms, and t 8 discover whether the psychiatric disorder might have been induced by other factors, such as the patient's work, leisure, marriage, or other relationships. If it seems likely that the psychiatric disorder primary then the indications for psychiatric treatment should be reviewed. Such treatment might include general psychologiced measures such as explanation, reassurance, and discussion of problems; specific psychological approaches such as anxiet⿳亠丷厂 management $^{29}$ or cognitive therapy, ${ }^{29}$ and anxiolytic or ant depressant medication. In carefully chosen cases such measurés may be the most effective treatment for the patient with bot psychiatric symptoms and gynaecological complaints and may reduce the indications for gynaecological surgery

Warm thanks are expressed to Doctors M J V Bull, S R Burne, $H$ Leggatt, A I M Neill, and A Taylor, of health centre A, and Doctors D Richards, Patrick Lawrence, $S \mathrm{~J}$ Wood, and Marion K Anscombe, of heal centre $B$, who kindly allowed us to see their general practice patients. We afe also grateful to Dr Peter Cooper and Dr Judith Ferguson for advice, and to Virginia Souilah for generous secretarial help. We thank Oxford Regionä Health Authority and Oxfordshire Health Authority for financial support.o

\section{References}

1 Snaith L, Ridley B. Gynaecological psychiatry: a preliminary report on an experimental clinic. BrMed f 1948;ii:418-21.

2 Rogers FS. Emotional factors in gynecology. Am 7 Obstet Gynecol 1950;59:321-7.

3 Smith DH. Psychologic aspects of gynecology and obstetrics. Obstet Gynecol Annu 1979;8:457-73. Munro A. Psychosomatic aspects of gynaecology. In: Kellar RJ, ed. Modern trends in gynaecolog, London: Butterworths, 1969:215-34.

5 Ballinger B. Psychiatric morbidity and the menopause: survey of a gynaecological out-patie clinic. Brf Psychiatry 1977;131:83-9.

6 Worsley A, Walters WAW, Wood ECC. Screening for psychological disturbance amongol gynaecology patients. Aust NZ J Obstet Gynaecol 1977;17:214-9.

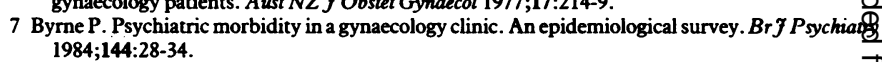

8 Goldberg DP. The detection of psychiatric illness by questionnaire. London: Oxford University Prese

9 Cohen ME, Robins E, Purtell JJ, Altman MW, Reid DA. Excessive surgery in hysteria. JAMA 1953;151:977-86.

10 Coppen A. The prevalence of menstrual disorders in psychiatric patients. $\mathrm{Br} \mathcal{F}$ Psychial 1965;111:155-67.

11 Wood C. Dysmenorrhoea. In: Dennerstein L, Burrows GD, eds. Handbook of psychosoma obstetrics and gynaecology. Amsterdam: Elsevier Biomedical Press, 1983:173-97.

12 Clare AW. Psychiatric and social aspects of pre-menstrual complaint. Psychol Med 1983;monogr suppl 4:1-58.

13 Ballinger CB. Psychiatric morbidity and the menopause; screening of general population sample BrMed F 1975;iii:344-6.

14 Gath D, Cooper P, Day A. Hysterectomy and psychiatric disorder. I. Levels of psychiati morbidity after hysterectomy. Br F Psychiatry 1982;140:335-50. 15 Bungay GT, Vessey MP, McPherson CK. Study of symptoms in middle life with special referengs
to the menopause. Br Med f $1980 ; 281: 181-3$.

16 Winokur G. Depression in the menopause. Am $\mathcal{F}$ Psychiatry 1973;130:92-3.

17 Winokur G, Cadoret $R$. The irrelevance of the menopause to depressive illness. In: Sachar EJ, ePD 18 Weissman MM, Klerman GL. Sex differences and the epidemiology of depression. Arch Gg Psychiatry 1977;34:98-111.

19 Shepherd M, Cooper B, Brown AC, Kalton CW. Psychiatric illness in general practice. Londonf Oxford University Press, 1966

20 Skegg DC, Doll R, Perry J. Use of medicines in general practice. Br Med f 1977;i:1561-3.

21 Wing JK, Coopper JE, Sartorius N. The measurement and classification of psychiatric symptom(s) London: Cambridge University Press, 1974.

22 Eysenck HJ, Eysenck SBG. The Eysenck personaliny inventory. London: University of Lond 6

23 Cooper P, Osborn M, Gath D, Feggetter G. Evaluation of a modified self-report measure of socifi adjustment. Br $\mathcal{F}$ Psychiatry 1982;141:68-75.

24 Paykel EK. Life stress and psychiatric disorder. In: Gunderson EK, Rahe RH, eds. Life stress and

25 Wilng JK. A technique for studying psychiatric morbidity in in-patient and out-patient series and

26 Surtees PG, Dean C, Ingham JG, Kreitman NB, Miller PM, Sashidharan SP. Psychiatric disord in women from an Edinburgh community: association with demographic factors. $\mathrm{Br}$ Psychiatry 1983;142:238-46.

27 Goldberg D, Kay C, Thompson L. Psychiatric morbidity in general practice and in th community. Psychol Med 1976;6:565-9.

28 Goldberg D, Huxley P. Mental illness in the community. London: Tavistock, 1980.

29 France R, Robson M. Behaviour therapy in primary care. London: Croom Helm, 1986.

(Accepted 28 October 1986) 